УДК 633.521

(C) 2017

Столярчук Т. А., аспірант

(науковий керівник - доктор сільськогосподарських наук, професор, член-кореспондент

НААН Украӥни С. М. Каленська)

Кисильчук А. М., махістр

Національний університет біоресурсів та природокористування України

\title{
ПОРІВНЯЛЬНА ХАРАКТЕРИСТИКА МОРФОЛОГІЧНИХ ОСОБЛИВОСТЕЙ СОРТІВ ЛЬОНУ ОЛІЙНОГО В УМОВАХ ПРАВОБЕРЕЖНОГО ЛІСОСТЕПУ УКРАЇНИ
}

\section{Рецензент - кандидат сільськогосподарських наук В. Б. Кутовенко}

Сорти льону олійного мають важливе значення для отримання його стабільного врожаю високої якості. Проте для льону олійного виявлена значна варіабельність ознак насіннєвої продуктивності (кількість та маса насіння з рослини, маса 1000 насінин) $і$ біохімічного складу насіння, однак відомості про реалізацію генотипового потенціалу культури обмежені. Саме через таку мінливість ознак льону олійного метою нашого дослідження було порівняння морфології рослин різних сортів під час вирощування саме в умовах Правобережного Лісостепу Украӥни. Проведені дослідження показали, що умови вирощування мають вплив на такі генотипові ознаки як висота рослин та кількість коробочок на рослині. Маса 1000 насінин та кількість насінин у коробочизі є відносно стабільними показниками $i$ мають незначну мінливість. Маса насіння з однієї рослини залежить від кількості коробочок на рослині, про щзо свідчить високий коефіцієнт корелячії. Найбільшу висоту рослин за всі роки досліджень мав сорт Лірина, найменшу - сорт Айсберг. Найвищу масу 1000 насінин мав сорт Південна ніч. Кращими за продуктивністю однієї рослини в умовах Правобережного Лісостепу України виявились сорти Еврика, Лірина та Блакитно-помаранчевий.

Ключові слова: льон олійний, Lіпит usitatissimum, сорт, продуктивність, висота, маса 1000 насінин.

Постановка проблеми. В даний час інтенсифікація сільськогосподарського виробництва йде двома шляхами: виведення нових сортів відповідного рівня врожайності і якості продукції та розробка системи землеробства, агротехнічних прийомів. Напрямок зі створення нових сортів використовує теоретичні розробки моделей сортів 3 певними ознаками і властивостями, які відповідають високим рівням врожаю і його якості в заданих умовах середовища [3].

Харчове, кормове, технічне й інше застосування льону олійного (Linum usitatissimum L.) диктує необхідність цілеспрямованого пошуку вихідного матеріалу з заданими властивостями для селекції різних за напрямками використання, адаптивними властивостями і якістю сортів $[5,8]$.

Серед великої кількості сортів найбільш цінними для сільського господарства будуть ті, які мають більш високий середній рівень врожайності та якості насіння і водночас менший розмах коливань ознак у мінливих умовах вирощування, тобто будуть пластичними [1].

Аналіз основних досліджень і публікацій, у яких започатковано розв'язання проблеми. Висока чутливість окремих сортів до несприятливих умов вирощування часто звужує ареал їх поширення в інші екологічні зони й обмежує їх загальне розповсюдження. Саме тому розширення норми реакції сортів на умови довкілля $є$ основним завданням селекції. На підставі випробування сортів льону олійного в різних регіонах вирощування можна прогнозувати генетично визначену ступінь стабільності (пристосованості до умов вирощування) їх врожайності.

Виробництво льону олійного в сучасних умовах базується на вирощуванні високоврожайних, високоолійних, стійких до основних патогенів сортах, які гарантують отримання товарної продукції, яка відповідає світовим стандартам якості. Під час вибору сорту для вирощування в тому чи іншому регіоні необхідно враховувати його генетичний потенціал, біологічні особливості та цілі використання [7].

На думку А. В. Юника правильний вибір сортів льону олійного має вирішальне значення для його успішного вирощування [10].

Отже, можна зробити висновок, що сорти льону олійного мають важливе значення для отримання стабільного його врожаю високої якості [4].

Проте для льону олійного виявлена значна варіабельність ознак насіннєвої продуктивності (кількість та маса насіння з рослини, маса 1000 насінин) і біохімічного складу насіння, однак відомості про реалізацію генотипового потенці- 


\section{СТОРІНКА МОЛОДОГО ВЧЕНОГО}

алу культури обмежені. Так, існує вплив погодних умов i географічних чинників на вміст $\mathrm{i}$ якість олії: в залежності від умов середовища коливання олійності сорту можуть становити 36,4-52,0 \%, різкі коливання температури в період дозрівання викликають відносно більше накопичення ненасичених жирних кислот $[9,11]$.

Через таку мінливість ознак льону олійного метою нашого дослідження було порівняння морфології рослин різних сортів льону олійного під час вирощування саме в умовах Правобережного Лісостепу України.

Завданням досліджень було виявлення впливу умов вирощування на морфологію льону олійного, вибір найбільш продуктивних сортів для даної зони.

Матеріали і методика досліджень. Дослідження проводились протягом 2016-2017 роках у стаціонарному досліді кафедри рослинництва ВП Національного університету біоресурсів i природокористування України «Агрономічна дослідна станція» (с. Пшеничне, Васильківський район, Київська область).

Грунт дослідної ділянки - чорнозем типовий малогумусний, за гранулометричним складом грубопилувато-середньосуглинковий зі вмістом гумусу в орному шарі грунту 4,53-4,38 \%, pH сольової витяжки 6,8-7,3. Площа дослідної ділянки -

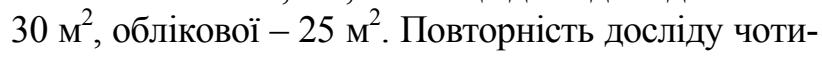
риразова, розміщення варіантів послідовне [2].

Технологія вирощування - загальноприйнята для даної культури. Норма висіву - 6 млн схожих насінин/га, ширина міжрядь - 12,5 см. У дослідженнях використовувались сорти вітчизняної селекції Айсберг, Водограй, Південна ніч Інституту олійних культур НААН України; Блакитно-помаранчевий і Еврика Інституту землеробства НААН та німецький сорт Лірина.

Відбір пробних снопів та визначення структури врожаю проводили за методикою державного сортовипробування сільськогосподарських культур (1985) [6].
Результати дослідження. Під час проведення досліджень аналізувалась висота рослин, кількість коробочок на одній рослині та кількість насінин 3 однієї рослини сортів, вирощених в умовах Правобережного Лісостепу України протягом 2016-2017 рр. (див. табл.). Аналіз снопових зразків показав, що висота льону олійного різних сортів різнилась між собою.

Висота рослин для льону олійного має особливе значення. Незважаючи на те, що льон олійний вирощується в першу чергу задля отримання насіння цієї культури, вміст трести в рослинах залишається доволі високим. У минулому, за часів СРСР, треста 3 льону олійного використовувалася на виготовлення шпагату, паклі для будівництва тощо і вся солома після збирання здавалася на переробку. На сьогоднішній день такого попиту на неї немає. Проте розвиток альтернативних джерел енергіі, екологічного будівництва та інших перспективних напрямків $є$ дуже цікавими нішами для використання побічної продукції вирощування льону олійного. На додаток варто вказати, що реалізація побічної продукції збільшить рентабельність виробництва i чистий прибуток, а також вирішить таку технологічну проблему як розклад соломи льону олійного на полях.

Абсолютним лідером, серед досліджуваних сортів, за цією ознакою $є$ сорт Лірина з середнім показником 57,82 см. Тому саме цей сорт можна рекомендувати для подвійного використання (для отримання насіння та трести). Найнижчу висоту мав сорт Айсберг - 45,87 см. Решта сортів мали близькі значення. Аналізуючи висоту рослин у розрізі років, слід зазначити, що вона суттєво різнилася. Так, наприклад, висота сорту Лірина в 2016 році становила 68,8 см, а в 2017 46,83 см; сорту Айсберг - 53,6 та 38,13 відповідно. Отже, можна зробити висновок про істотний вплив погодних умов року вирощування на досліджувану ознаку.

Морфологічні особливості сортів льону олійного (середнє за 2016-2017)

\begin{tabular}{|c|c|c|c|c|c|}
\hline Сорт & $\begin{array}{c}\text { Висота рос- } \\
\text { лин, см }\end{array}$ & $\begin{array}{c}\text { Кількість коробо- } \\
\text { чок на рослині, шт. }\end{array}$ & $\begin{array}{c}\text { Кількість насінин } \\
\text { в коробочці, шт. }\end{array}$ & $\begin{array}{c}\text { Маса насіння, } \\
\text { грослини }\end{array}$ & $\begin{array}{c}\text { Маса 1000 } \\
\text { насінин, г }\end{array}$ \\
\hline Айсберг & 45,87 & 13,15 & 7,19 & 0,690 & 7,56 \\
\hline $\begin{array}{c}\text { Блакитно- } \\
\text { помаранчевий }\end{array}$ & 54,20 & 22,60 & 6,37 & 0,809 & 5,35 \\
\hline Водограй & 51,15 & 11,55 & 8,52 & 0,716 & 6,87 \\
\hline Еврика & 52,35 & 22,00 & 8,25 & 0,979 & 5,90 \\
\hline Лірина & 57,82 & 15,05 & 8,56 & 0,855 & 6,15 \\
\hline Південна ніч & 53,20 & 11,50 & 6,44 & 0,618 & 8,15 \\
\hline
\end{tabular}




\section{СТОРІНКА МОЛОДОГО ВЧЕНОГО}

Аналізуючи кількість коробочок на рослині, ми об'єднали сорти в дві групи по даному показнику. До сортів з великою кількістю коробочок на рослині можна віднести два сорти (Блакитнопомаранчевий та Еврика), у яких цей показник значно перевищував аналогічні показники інших сортів і становив 22,6 та 22,0 шт. відповідно. Інша група - сорти 3 середньою кількістю коробочок на рослині, це 4 сорти (Айсберг, Водограй, Лірина та Південна ніч). У цих сортів даний показник варіювався в межах 11,55-15,05 шт. Кількість коробочок на рослині мала високу варіабельність у розрізі років - для сорту Блакитнопомаранчевий 26,9 шт. у 2016 та 18,3 у 2017; відповідно 13,1 та 9,9 для сорту Південна ніч; 26,3 та 17,7 для сорту Еврика. Отже, можна зробити висновок про суттєвий вплив умов вирощування на дану ознаку.

3 отриманих результатів бачимо, що за показником кількості насінин в 1 коробочці сорти не дуже відрізняються. Проте тут можна виділити три сорти, а саме Еврика, Лірина та Блакитнопомаранчевий, у яких даний показник знаходиться вище за інші сорти. Враховуючи те, що згідно 3 біологічними особливостями рослини льону даний показник не може бути більшим за 10 шт. ми можемо зробити висновок, що всі сорти мають гарні показники. А говорячи про сорти, які показали найвищі результати варто зазначити те, що вони наближаються до біологічного максимуму, тобто мають високий потенціал врожайності. Порівнюючи кількість насінин в 1 коробочці з іншими показниками ми дійшли висновку, що цей показник є більше сортовою ознакою і не суттєво змінюється від агротехніки вирощування чи погодно-кліматичних умов.

Показник маси 1000 насінин $є$ дуже важливим для будь-якої культури. Він характеризує такі показники, як крупність насіння, його виповненість, які в свою чергу впливають на кількісні і якісні ознаки врожаю та застосування насіння в якості посівного матеріалу. За даним показником практично всі сорти у нашому досліді були рівні

\section{БІБЛІОГРАФІЯ}

1. Вавилов Н.И. Избранные труды / Н. И. Вавилов. - М. : Колос. $-1966 .-588$ с.

2. Дослідна справа в агрономії : навч. посібник : у 2 кн. - Кн.1. Теоретичні аспекти дослідної справи / [Рожков А. О., Пузік В. К., Каленська С. М. та ін.] ; за ред. А. О. Рожкова. Х. : Майдан. - 2016. - 316 с.

3. Коваль С. Ф. Стратегия и тактика отбора в селекции растений : монографія / С. Ф. Коваль, і займали діапазон значень від 5,35 г у сорту Блакитно-помаранчевий до 7,56 г у сорту Айсберг. Проте один сорт виділявся 3-поміж інших за цим показником. Це Південна ніч $з$ рівнем маси 1000 насінин 8,15 г. Це говорить нам про стабільність сорту, адже в рівних умовах лише сорт Південна ніч показав заявлені характеристики по цьому показнику, крім того даний сорт мав найменші відхилення даного показника в розрізі років $(8,15$ г у 2016 та 8,16 у 2017 році). Кореляційний аналіз показав, що не зважаючи на те, що він і має певні взаємозв'язки з іншими елементами структури врожаю, проте є більше сортовою ознакою, яка незначною мірою залежить від умов вирощування.

Наступний показник характеризує врожайність сортів льону олійного визначену лабораторним методом. Маса насіння 31 рослини варіювала в межах від 0,618 г у сорту Південна ніч до 0,979 г у сорту Еврика, яка тісно пов'язана з показником урожайності, а тому $є$ показовим для характеристики факторів впливу на врожайність рослин льону олійного. I як показує високий коефіцієнт кореляції - залежить від кількості коробочок на рослині.

Висновок. Умови вирощування мають вплив на такі генотипові ознаки, як висота рослин та кількість коробочок на рослині. Маса 1000 насінин та кількість насінин в коробочці $є$ відносно стабільними показниками і мають незначну мінливість. Маса насіння з однієї рослини залежить від кількості коробочок на рослині, про що свідчить високий коефіцієнт кореляції. Найбільшу висоту рослин за всі роки досліджень мав сорт Лірина, найменшу - сорт Айсберг. Найвищу масу 1000 насінин мав сорт Південна ніч. Кращими за продуктивністю однієї рослини в умовах Правобережного Лісостепу України виявились сорти Еврика, Лірина та Блакитно-помаранчевий, саме ці сорти можна рекомендувати для вирощування в умовах Правобережного Лісостепу України. Для подвійного використання найкраще підходить сорт Лірина.

В. П. Шаманин, В. С. Коваль. - Омск : Изд-во ФГОУ ВПО ОмГАУ. - 2010. - 228 с.

4. Льон олійний: біологія, сорти, технологія вирощування / [Чехов А. В., Лапа О. М., Міщенко Л. Ю., Полякова І. О.]. - К. : [Б. в.]. - 2007. $59 \mathrm{c}$.

5. Маслинская М. Е. Источники хозяйственно ценных признаков для создания сортов льна масличного, адаптированных к условиям Бела- 
руси / М. Е. Маслинская, Е. Л. Андроник // Вестник БГСХА. - 2013. - №2. - С. 88-93.

6. Методика государственного сортоиспытания сельскохозяйственных культур. - М., 1985. - Вып. 3. - 184 с.

7. Перспективная ресурсосберегающая технология производства льна масличного : метод. рек. - М. : ФГНУ «Росинформагротех». - 2010. $52 \mathrm{c}$.

8. Титок B. В. Физиология и биохимия льна / В. В. Титок, В. А. Лемеш, С. И. Юренкова, Л. В. Хотылева. - Минск : «Беларуская навука». $-2010 .-335$ c.
9. Щербаков В. Г., Лобанов В. Г. Биохимия и товароведение масличного сырья / В. Г. Щербаков, В. Г. Лобанов. - М. : Колос. - 2003. - 360 с.

10. Юник A. В. Особливості вирощування льону олійного / А. В. Юник // Пропозиція. - 2015. №11. - С. 76-80.

11. Diederichsen A., Raney J. P. Seed colour, seed weight and seed oil content in Linum usitatissimum accessions held by Plant Gene Resources of Canada / A. Diederichsen, J. P. Raney // Plant Breed. - 2006. -Vol. 125. - №4. - P. 372377. 